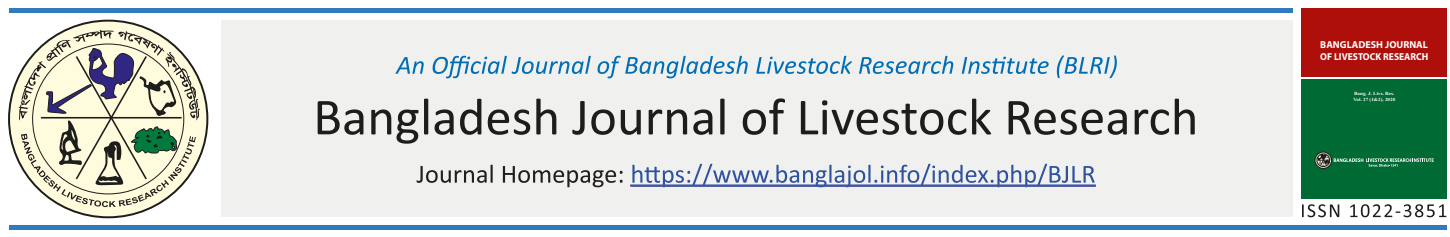

\title{
Biochemical property analysis of native probiotic isolates from selective poultry
}

\author{
K. M. Hossain ${ }^{1 *}$, A.K. Das ${ }^{1}$, S.M.M. Rahman ${ }^{1}$, S. Roy ${ }^{1}$ and M.A. Hamid ${ }^{1}$ \\ ${ }^{1}$ Biotechnology and Genetic Engineering Discipline, Khulna University, Khulna-9208, \\ Bangladesh \\ ${ }^{2}$ School of Agriculture and Rural Development, Bangladesh Open University, Gazipur-1705, \\ Bangladesh
}

\begin{abstract}
Isolation and identification of probiotic bacteria are the prerequisites for their safer use in the food and feed industry. The objectives of the present study were the isolation of probiotic bacteria from the selective gastrointestinal tract of poultry obtained from Khulna and Barisal Divisions, and their identification based on bacterial morphological characterization and biochemical property analysis. Ten potential native probiotics were isolated from the poultry gastrointestinal tract and assayed for their morphological, physiological and biochemical properties. It was observed that, all the isolates were rod-shaped, gram-positive, endospore-negative, catalase-negative, non-motile and were able to ferment particular sugars which are an indicator for typical probiotic bacteria. The sugar fermentation pattern, ability to survive and growth in inhibitory substances like $1-4 \% \mathrm{NaCl}, 0.3 \%$ bile salt as well as their ability to grow in different temperatures and $\mathrm{pH}$ levels ensured the presumptive identification of the lactic acid bacteria. All the ten isolates exhibited a clear zone of inhibition when they were grown with five enteric pathogens which are indicative of their antimicrobial activity. Ten isolates were assayed for their susceptibility to eight antibiotics using the disc diffusion method. All the isolates were resistant to tetracycline and nalidixic acid. Further research regarding molecular characterization and identification of specific genes using different technologies may open the door to utilize these isolates in different probiotic-based inventions.
\end{abstract}

Key words: Lactobacillus, Probiotics, Antimicrobial Activity, Inhibitory substances

Bang. J. Livs. Res. Vol. 27 (1\&2), 2020: P. 39-54 https://doi.org/10.3329/bjlr.v27i1.55168

\section{Introduction}

The probiotic concept was originally used by Lilly and Stillwell (1965) to indicate a substance that stimulates the growth of other

*Corresponding author: mahossain@cvasu.ac.bd 
microorganisms. The term "probiotic", a curious mixture of Latin (pro = for, in favor of) and Greek (bios = life) was coined, as opposed to "antibiotic", in the 1960s to define substances produced from protozoa and able to support the growth of other microorganisms (Lilly and Stillwell, 1965). The term probiotic means "for life", originated from the Greek words "pros" and "bios" (Gismondo et al., 1999). Lactic acid bacteria (LAB) comprise a wide range of genera and include a considerable number of species. Lactobacillus is one of the most important genera of LAB (Coeuret et al., 2003). According to Coeuret et al. (2003), its common features are: Gram-positive, generally catalase-negative, grows in microaerophilic conditions, produces anaerobic acid and lactic acid. These bacteria are the natural components of gastrointestinal microflora. There are different mechanisms of action of probiotics that includes: elimination of free radicals, production of bacteriocins (Cotter et al., 2013), influence on the gene expression of intestinal mucin (Aliakbarpour et al., 2012), the exclusion and inhibition of pathogens (Adlerberth et al., 2000), and the attenuation of virulence (Mohan, 2015). Today, the universal meaning of the term "probiotic" has been established by the World Health Organization and the United States Food and Agriculture Organization. These two organizations defined probiotics as living micro-organisms that, when administered in adequate quantities, have a beneficial effect on the health of the host organism (Corcionivoschi et al., 2010). Such microorganisms may not necessarily be constant inhabitants of GIT but should have a beneficial effect on the health status of humans and animals. In relation to food, probiotics are considered as "feasible preparations in foods or food supplements to improve the health of humans and animals" (Holzapfel et al., 2001). Probiotics, compared to animal applications, are defined as live microbial food supplements that beneficially improve the intestinal microbial balance in a host animal (Ibrahim et al., 2010). According to these definitions, an impressive number of microbial species and genera are considered probiotics. Among these, those that should beneficially influence the host by improving the intestinal microbial balance, and are therefore, selected as probiotics including species of the genera Lactobacillus, Bifidobacterium, Bacillus, Saccharomyces and Enterococcus (Soccol et al., 2010). Representative species include Lactobacillus acidophilus, Lactobacillus johnsonii, Lactobacillus gasseri, Lactobacillus casei, Lactobacillus rhamnosus, Lactobacillus plantarum, Bifidobacterium bifidum, Bifidobacterium infantis, Enterococcus faecalis and Enterocucus faecium. In particular, Lactobacilli are being used as probiotics. This may have historical reasons from Metchnikoff that present Lactobacilli in yogurt would have a health promoting effect. However, other microbes and even yeasts have developed as potential probiotics (Ouwehand et al., 2002). Some bacteria that do not live in the intestinal tract can also be included in the probiotic categories which include mainly Lactobacillus bulgaricus, Streptococcus termofili, Leuconostocand Lactococcus species (Ishibashi and Yamazaki, 2001). Therefore, to explore the possibilities of probiotic properties, the present research work was undertaken with the following 
objectives: Isolation and identification of bacteria from the gastrointestinal tract of chicken and duck.

Analysis of probiotic potentiality of native bacterial isolates

\section{Materials and Methods}

\section{Collection of samples}

Healthy broiler chickens and ducks of 15 and 30 days old were collected from different farms of Khulna and Barisal Divisions (Table 1). They were then sacrificed and different parts of the gastrointestinal tract (GIT) viz. crop, small intestine and ceca were aseptically collected using the sterile scalpel in sterile petri dishes (Ali et al, 2020).

\section{Isolation of probiotic bacteria from selected poultry GIT}

Collected different parts of poultry GIT were cut into small pieces and then tissue mass were ground until homogenized. Then each sample was dissolved with its content in $9 \mathrm{ml}$ of $0.15 \%$ buffered peptone water solution and diluted up to 10-10 fold. The diluted sample was inoculated into the MRS agar plate by ensuring a $6.5 \mathrm{pH}$ value and incubated at $37^{\circ} \mathrm{C}$ temperature. Then each sample was subcultured three times to obtain purified bacteria with homogenous morphology. The isolated culture was maintained in MRS broth at $\mathrm{pH}$ 6.5. Colonies with typical characteristics were randomly selected and collected from plates and then tested for colony morphology, gram staining, endospore test, catalase test, motility test, and sugar fermentation tests. At the time of the bacterial characterization test, the cultures were refrigerated at $4{ }^{\circ} \mathrm{C}$ in an MRS agar medium.

\section{Bacterial characterization}

\section{Colony morphology test}

The purified bacteria were subcultured continually on MRS agar media by plate streaking method and the colony morphologies (color, shape, and size) were examined. However, microscopic observation was needed to separate one colony from another.

\section{Gram staining}

At first single colony was taken aseptically and then smeared on to a clean dry slide and heat-fixed. The heat-fixed smear was flooded with crystal violet solution for $30 \mathrm{sec}$ and rinsed with water for $5 \mathrm{sec}$. Then grams iodine solution was used to cover over the slide for 1 minute and then rinsed with tap water for 5 sec. Then $95 \%$ ethanol was used for decoloring the slide for 15 to $30 \mathrm{sec}$ and again rinsed with $5 \mathrm{sec}$. Finally, Safranin was used as counter stains for $60-80 \mathrm{sec}$ and further rinsed with water and then the isolates were scrutinized under the light microscope. Gram positive bacteria became blue purple after gram staining (Coico, 2006).

\section{Endospore test}

A single colony was aseptically taken by using inoculating loop and then smeared onto a clean dry slide, later on air dried and heat-fixed. The slide was covered using blotting paper and then soaked with malachite green and was heated for 5 minutes to steam the stain and then more dye was added as required. The blotting paper was removed and allowed the slide to cool and rinsed with tap water for $30 \mathrm{sec}$. Finally, Safranin was used for 60 to $80 \mathrm{sec}$ and then examined under the light microscope. The vegetative cells stained as red and the endospore and free spore both stained as green. 
Table 1: Sources of Poultry Samples Collected from Khulna and Barisal Divisions

\begin{tabular}{c|c|c|c}
\hline $\begin{array}{c}\text { Sources } \\
\text { of Isolates }\end{array}$ & $\begin{array}{c}\text { Isolate } \\
\text { Identity }\end{array}$ & $\begin{array}{c}\text { Sample } \\
\text { Type(Age) }\end{array}$ & Name of the Divisions \\
\hline Crop & Cr1 & Duck(15d) & Khulna \\
\hline Small intestine & SI1 & Duck(15d) & Khulna \\
\hline Crop & Cr2 & Chicken(15d) & Khulna \\
\hline Cecum & C2 & Chicken(15d) & Khulna \\
\hline Small intestine & SI2 & Chicken(15d) & Khulna \\
\hline Cecum & C3 & Chicken(15d) & Khulna \\
\hline Crop & Cr4 & Chicken(15d) & Barisal \\
\hline Cecum & C4 & Chicken(15d) & Barisal \\
\hline Small intestine & SI5 & Chicken(30d) & Barisal \\
\hline Crop & Cr5 & Chicken(30d) & \\
\hline
\end{tabular}

\section{Motility test}

At first semi-solid MIL (Motility Indole Lysine) medium was used to test the motility of the isolated bacteria. A well isolated colony was picked using a needle and the media was stabbed with it within 1 $\mathrm{cm}$ of the bottom of the tube. The needle was kept in the same position during removal. Incubation was done for 18 hours at $37^{\circ} \mathrm{C}$ or until the growth was evident. Salmonella typhi was used as a positive control in this test.

\section{Catalase test}

A clean glass slide was divided into sections with a grease pencil. One was labeled as a test and the other was the positive control. A sterile loop was taken and a drop of normal saline was placed on each area and then a small amount of the culture was taken from the MRS agar slant or Petri dishes. One or two colonies were emulsified on each drop to make a smooth suspension. One drop of $3 \%$ hydrogen peroxide was given over the test smear. Salmonella typhi was used as the positive control. The fluid was observed over the smears for the appearance of gas bubbles.

\section{Sugar Fermentation profile determination}

The isolated bacteria were screened for their ability to ferment 10 different carbohydrates and all the reactions were performed three times in test tubes. First active cell culture was prepared. For that, overnight activation of isolates was prepared in $10 \mathrm{ml} \mathrm{MRS} \mathrm{at}$ $42^{\circ} \mathrm{C}$. Then centrifugation was done for 10 $\min$ at $10000 \mathrm{rpm}$. The pellet was resuspended in $5 \mathrm{ml}$ MRS without glucose and containing bromocresol purple. The modified MRS medium was used for carbohydrate fermentation. Centrifugation was done for $10 \mathrm{~min}$ at $10000 \mathrm{rpm}$. The pellet was resuspended in an actual volume of $10 \mathrm{ml}$ MRS without glucose and containing bromocresol purple. Then the test sugar solution was prepared. For that, each sugar was dissolved in distilled water at the final concentration of $5 \%(\mathrm{w} / \mathrm{v})$ and 
then the sugar solutions were sterilized using filters of $0.22 \mu \mathrm{m}$ pore diameter. A test tube was taken and $5 \mathrm{ml}$ of MRS broth was added without glucose and containing bromocresol purple. One $\mathrm{ml}$ of sugar solution (5\%) was pipetted into the test tube and $100 \mu$ active cell solution was inoculated without sugar into the broth. Two negative controls (culture containing no sugar solution and sugar solution containing no active cell culture) were used for the indication of any contamination coming from basal media or any activity problem with culture. After overnight incubation at $42^{\circ} \mathrm{C}$, the turbidity was recorded and the color change from purple to yellow with respect to negative controls was recorded as a positive fermentation result (Hedberg et al., 2008).

\section{Probiotic property analysis of the native bacterial isolates from poultry GIT $\mathrm{NaCl}$ tolerance test}

For the determination of $\mathrm{NaCl}$ tolerance of isolated bacterial species, MRS broth was adjusted with different concentrations (1-10) \% of $\mathrm{NaCl}$. After sterilization, each test tube was inoculated with $1 \%$ fresh overnight culture of Lactic Acid Bacteria (LAB) and then incubated at $37^{\circ} \mathrm{C}$ for $24 \mathrm{~h}$. After $24 \mathrm{~h}$ of incubation, growth was confirmed by observing their turbidity.

\section{Growth on various temperatures}

For the determination of growth on various temperatures, MRS broth was inoculated with one colony of the fresh over-night culture of $\mathrm{LAB}$ and then incubated at $25^{\circ} \mathrm{C}$, $35^{\circ} \mathrm{C}$ and $45^{\circ} \mathrm{C}$ for $24 \mathrm{~h}$. At the time points evaluated, each sample was streaked into MRS agar to monitor growth. The turbidity of each tube was also noted as an indication of growth or no growth. The test was performed in triplicates.

\section{Growth at different pH}

Tolerance of LABs to different $\mathrm{pH}$ was determined by the growth of bacteria in MRS broth having $\mathrm{pH} 3.5,4.0,5.0,8.0$ and 9.0. The $\mathrm{pH}$ was adjusted with $1 \mathrm{~N} \mathrm{HCL}$ and $0.5 \mathrm{~N} \mathrm{NaOH}, 1 \%$ fresh overnight culture of isolated bacteria was inoculated into MRS broth having $\mathrm{pH} 3.5,4.0,5.0,8.0$, and 9.0 and then incubated at $37^{\circ} \mathrm{C}$ for 24 hours. After $24 \mathrm{~h}$ incubation, each sample was streaked onto MRS agar to determine the presence and absence of growth, which was used to confirm livability of strains. The turbidity of each tube also was noted as an indication of growth or no growth.

\section{Bile tolerance test}

MRS broth with different concentrations $(0.05 \%, 0.15 \%$ and $0.3 \%)$ of bile ox-gall was adjusted to final $\mathrm{pH} 6.5$ and sterilized by autoclaving at $121^{\circ} \mathrm{C}, 15 \mathrm{psi}$ pressure for 15 minutes. After that, $1 \%(\mathrm{v} / \mathrm{v})$ overnight bacterial culture was inoculated into the MRS broth medium. The survival rate of the isolates in different concentrations of MRS medium was determined by measuring the Abs. in a spectrophotometer at $620 \mathrm{~nm}$ after $0,3,6$, and $24 \mathrm{~h}$ of incubation at $37^{\circ} \mathrm{C}$. The uninoculated MRS broth at different concentration was used as a blank.

\section{Antimicrobial activity test}

Lactic acid bacterial cells were removed by centrifuging the culture at $10000 \mathrm{rpm}$ for 10 min. The $\mathrm{pH}$ of the Cell-Free Supernatant (CFSs) was adjusted to 6.5 by the addition of $1 \mathrm{~N} \mathrm{NaOH}$. CFSs were filtered $(0.22 \mu \mathrm{m}$ pore size) and stored at $4{ }^{\circ} \mathrm{C}$.

This assay was performed in triplicates. The 
plates were poured with $20 \mathrm{ml}$ nutrient agar media. The pathogenic strains were grown in nutrient broth for 24 hours. The pathogenic strains were adjusted to $(10) \wedge 7$ $\mathrm{cfu} / \mathrm{ml}$ by adding sterile distilled water and spread on the surface of the nutrient agar plate. Four wells in each plate of 8 millimeter $(\mathrm{mm})$ in diameter were cut into these agar plates by using sterile tips and $100 \mu \mathrm{l}$ of the CFSs of all isolates were placed into the different well. Uninoculated MRS broth was placed in one well as a control. The plates were pre-inoculated at $4^{\circ} \mathrm{C}$ for 3-4 hours for radial diffusion and then incubated aerobically overnight at $37^{\circ} \mathrm{C}$. The zones of inhibition were measured on $\mathrm{mm}$ with a transparent scale and noted down (Jorgensen et al., 2007). Antibiotic susceptibility test.

Each LAB isolate was spread evenly on MRS agar medium to make a bacterial lawn. The plates were allowed to dry for 5-15 minutes. Four antibiotic discs were placed on the surface of each agar in the center of the sectioned area and then the plates were incubated for $24-48$ hours at $37^{\circ} \mathrm{C}$ temperature anaerobically. After incubation, the diameter of a zone of inhibition was measured and recorded.

\section{Results}

\section{Identification of probiotic bacteria Colony morphology}

Colony morphology of the isolates has been shown in Table 3 from which it can be observed that the colony morphology of isolate no. 1, 2 and 3 were medium, circular, low convex and white colony from sample no. Cr1, SI1 and Cr2, respectively. Besides, small, round and non-transparent colonies were observed in the isolates $4,5,6,7$, and 8 from sample no. C2, SI2, C3, Cr4 and C4, respectively. Furthermore, small and triangular white colony was observed in isolates 9 and 10 from sample no. SI5 and Cr5, respectively.

\section{Gram staining}

All of the isolated bacteria were found gram positive due to their ability to retain violet-color which was considered as gram positive.

\section{Endospore test}

Microscopically all the isolated bacteria were negative which has shown in Table 3. Stained vegetative cells appeared as red and both endospore and spore appeared as green under the light microscope. From microscopic observation, the green color was not observed and that indicated the absence of endospores.

\section{Motility test}

In the case of all ten isolated bacteria, the growth-induced along the line of inoculation indicates the non-motile nature of the isolated bacteria. The growth of test isolates through the inoculation line indicates a negative result. Diffused growth of Salmonella typhi used as a positive control.

\section{Catalase test}

All the isolated bacteria were found catalase-negative which is given as a negative sign (Table 2) due to no bubble production in $3 \%$ hydrogen peroxide. Catalase enzyme breaks down hydrogen peroxide into oxygen and water bubbles.

The production of gas bubbles shows the presence of the enzyme (the catalasepositive nature of the bacterium). 
Table 2: Morphological and Biochemical Characteristics of the Isolated Bacteria Obtained from Poultry Samples of Khulna and Barisal Divisions

\begin{tabular}{c|c|c|c|c|c}
\hline \multirow{2}{*}{$\begin{array}{c}\text { Sources } \\
\text { of } \\
\text { Isolates }\end{array}$} & \multicolumn{5}{|c}{ Morphological and Biochemical Characteristics } \\
\cline { 2 - 6 } & $\begin{array}{c}\text { Colony } \\
\text { Morphology }\end{array}$ & $\begin{array}{c}\text { Gram } \\
\text { Staining }\end{array}$ & Catalase & Endospore & Motility \\
\hline Cr1 & Circular & + & - & - & - \\
\hline Si1 & Circular & + & - & - & - \\
\hline Cr2 & Circular & + & - & - & - \\
\hline C2 & Round & + & - & - & - \\
\hline Si2 & Round & + & - & - & - \\
\hline C3 & Round & + & - & - & - \\
\hline Cr4 & Round & + & - & - & - \\
\hline C4 & Round & + & - & - & - \\
\hline Si5 & Triangular & + & - & - & - \\
\hline Cr5 & Triangular & + & - & - & - \\
\hline
\end{tabular}

$(+)$ sign means isolates showed positive result and (-) sign means isolates showed negative result

\section{Sugar fermentation profile determination}

The sugar fermentation profile of all the ten isolates has been shown in Table 3. Ten different sugars were used to determine their sugar fermentation pattern. Gas production from sugar fermentation was also observed in the Durham tube. All the isolates fermented 8 sugars out of 10 . Only sorbitol and D-Xylose were not fermented by the isolates. Gas production was observed in all the fermented sugars. Sugar fermentation was identified when the red color was converted to yellow.

\section{Study of probiotic properties of isolated bacteria}

\section{Sodium Chloride ( $\mathrm{NaCl}$ ) tolerance test}

Isolates were tested for their tolerance against different $\mathrm{NaCl}$ concentrations. In the present study, 4 different concentrations of $\mathrm{NaCl}$ and one Control was used to determine the $\mathrm{NaCl}$ tolerance of bacterial isolates. All of the isolates showed tolerance against $2 \%$ and $4 \% \mathrm{NaCl}$. Fermentation was also observed in $\mathrm{NaCl}$ concentration after 24 hours of time. The growth of isolates reduced drastically in $6 \% \mathrm{NaCl}$ concentration. However, isolate no. 1 showed moderate tolerance in $6 \% \mathrm{NaCl}$ concentration. Almost no growth was observed in $8 \% \mathrm{NaCl}$ concentration while the growth was highest for all the isolates in the control group with no $\mathrm{NaCl}$ (Table 4).

\section{Growth on various temperatures}

Growth of the isolated bacteria was observed at $25^{\circ} \mathrm{C}, 35^{\circ} \mathrm{C}$ and $45^{\circ} \mathrm{C}$. All the isolates showed significant growth at $25^{\circ} \mathrm{C}$, $35^{\circ} \mathrm{C}$ and $45^{\circ} \mathrm{C}$ except isolate 6 which showed no growth at temperature $45^{\circ} \mathrm{C}$.

\section{Growth at different $\mathrm{pH}$}

Generally, probiotic bacteria show variable resistance to acidic conditions. To study this property of probiotics, the isolated bacteria were grown at different $\mathrm{pH}$. The growth of the isolates was normal at $\mathrm{pH}$ ranging from 3.5 to 9.0 in the first 24 hours of incubation (Table 4). However, after 24 hours of incubation, the isolates showed a decrease in 
Table 3: Sugar Fermentation Patterns of the Isolates obtained from Poultry Samples of Khulna and Barisal Divisions

\begin{tabular}{|c|c|c|c|c|c|c|c|c|c|c|}
\hline $\begin{array}{c}\text { Sources } \\
\text { of } \\
\text { Isolates }\end{array}$ & $\begin{array}{l}0 \\
0 \\
0 \\
0 \\
0\end{array}$ & 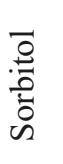 & 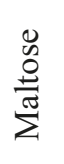 & 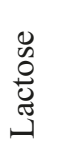 & $\begin{array}{l}0 \\
0 \\
0 \\
0 \\
0 \\
0\end{array}$ & 总 & $\frac{\infty}{\infty}$ & 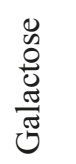 & 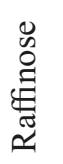 & 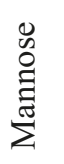 \\
\hline $\mathrm{Cr} 1$ & + & - & + & + & $+/-$ & + & - & + & + & + \\
\hline Sil & + & - & + & + & + & + & - & + & + & + \\
\hline $\mathrm{Cr} 2$ & + & - & + & + & + & + & - & + & + & + \\
\hline C2 & + & - & + & + & + & + & - & + & + & + \\
\hline $\mathrm{Si} 2$ & + & - & + & + & + & + & - & + & + & + \\
\hline C3 & + & - & + & + & + & + & - & + & + & + \\
\hline $\mathrm{Cr} 4$ & + & - & + & - & + & + & - & + & + & + \\
\hline C4 & + & - & + & + & + & + & - & + & - & + \\
\hline $\mathrm{Si} 5$ & + & - & + & + & + & + & - & + & + & + \\
\hline $\mathrm{Cr} 5$ & + & - & + & + & + & + & - & $+/-$ & - & + \\
\hline
\end{tabular}

(+) sign means isolates had the ability to ferment particular sugar, (-) sign means isolates did not have the ability to ferment particular sugar, (+/-) Means isolates could moderately ferment particular sugar

growth at $\mathrm{pH} 3.5$ and 4.0. In the other condition, the isolates showed normal growth after 24 hours of incubation.

\section{Bile salt tolerance test}

Isolated LABs were able to survive in $0.05 \%, \quad 0.15 \%$ and $0.3 \%$ inhibitory substance, bile acid (Table)

\section{Antimicrobial activity test}

The native probiotic isolates from poultry showed antimicrobial activity against few pathogens by inhibiting the growth of the pathogens which is indicated by the formation of inhibitory zones near the diffusion spots. Five different pathogenic bacteria Salmonella typhi, Salmonella para-typhi, Escherichia coli, Vibrio cholera, and Streptococcus aureus were used for this purpose. The diameter of inhibition zones showed that, most of the isolates have antimicrobial activity. All ten isolates were grown against the pathogens using the agar well diffusion method. The experiment was conducted three times and the mean diameters of inhibition zones have shown in (Figure 1). The mean diameter of the inhibitory zone varied from $13.33 \mathrm{~mm}$ to $24.08 \mathrm{~mm}$. Isolate no 1, 4, 5 and 7 showed the highest inhibitory activities against Escherichiacoli but isolate no 2 and 10 showed the lowest activities against Escherichia coli. Isolate no 2, 3, 6, 8, and 9 showed the highest antimicrobial activity against Salmonella para-typhi whereas isolate no 4 and 5 showed the lowest antimicrobial activity against Salmonella para-typhi. Isolate no 10 showed the highest inhibitory activity against Salmonella typhi but isolate no 1 and 3 showed the least activity 
Table 4: Analysis of Physico-chemical and Biochemical Properties of the Isolated Bacteria Obtained from Poultry Samples of Khulna and Barisal Divisions

\begin{tabular}{c|c|c|c|c|c|c}
\hline \multirow{2}{*}{$\begin{array}{c}\text { Sources of } \\
\text { Isolates }\end{array}$} & \multicolumn{5}{|c}{ Physico-chemical and Biochemical Properties of the Isolates } \\
\cline { 2 - 7 } & $\begin{array}{c}\mathrm{pH} \\
\text { Tolerance }\end{array}$ & $\begin{array}{c}\text { Bile Salt } \\
\text { Tolerance }\end{array}$ & \multicolumn{3}{c}{ NaCl Tolerance } \\
\cline { 2 - 7 } & $\mathrm{pH} 3.5-9.0$ & $0.3 \%$ & $2 \%$ & $4 \%$ & $6 \%$ & $8 \%$ \\
\hline Cr1 & + & ++ & ++ & ++ & + & - \\
\hline SI1 & + & ++ & ++ & ++ & - & - \\
\hline Cr2 & + & ++ & ++ & ++ & - & - \\
\hline C2 & + & ++ & ++ & ++ & - & - \\
\hline SI2 & + & ++ & ++ & ++ & - & - \\
\hline C3 & + & ++ & ++ & ++ & - & - \\
\hline Cr4 & + & ++ & ++ & ++ & - & - \\
\hline C4 & + & ++ & ++ & ++ & - & - \\
\hline SI5 & + & ++ & ++ & ++ & - & - \\
\hline Cr5 & + & ++ & ++ & ++ & - & - \\
\hline
\end{tabular}

$(++)$ sign means excellent growth, $(+)$ means moderate growth, $(-)$ sign means no growth

against Salmonella typhi. Isolate no 6 showed the least antimicrobial activity against Vibrio cholera whereas isolate no 7 , 8, 9, and 10 showed the lowest inhibitory activity against Streptococcus aureus.

\section{Antibiotic susceptibility test}

Ten isolates were assayed for their susceptibility to eight antibiotics using the disc diffusion method. Zone diameters were measured (Table 5) and the susceptibility of isolates were expressed as $\mathrm{S}$ (susceptible), MS (moderately susceptible) and R (resistant). The replication was done three times. All the isolates were resistant to tetracycline and nalidixic acid. Isolate 5, 6 and 10 were resistant to cefuroxime. Isolate no 1, 2, 3, 4, 9 and 10 were medium susceptible to clindamycin. Isolate no 1, 2, 3 and 8 were resistant to azithromycin. Isolate no. 4, 5, 6 and 10 were resistant to clavulanic acid.Isolate no 4 were resistant to amoxicillin but medium susceptible to resistant to both amoxicillin and penicillin. The diameter of the disc was $6 \mathrm{~mm}$.

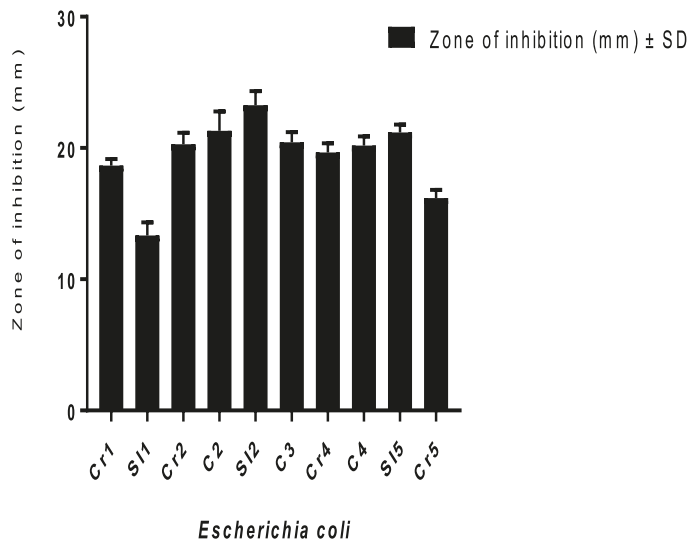



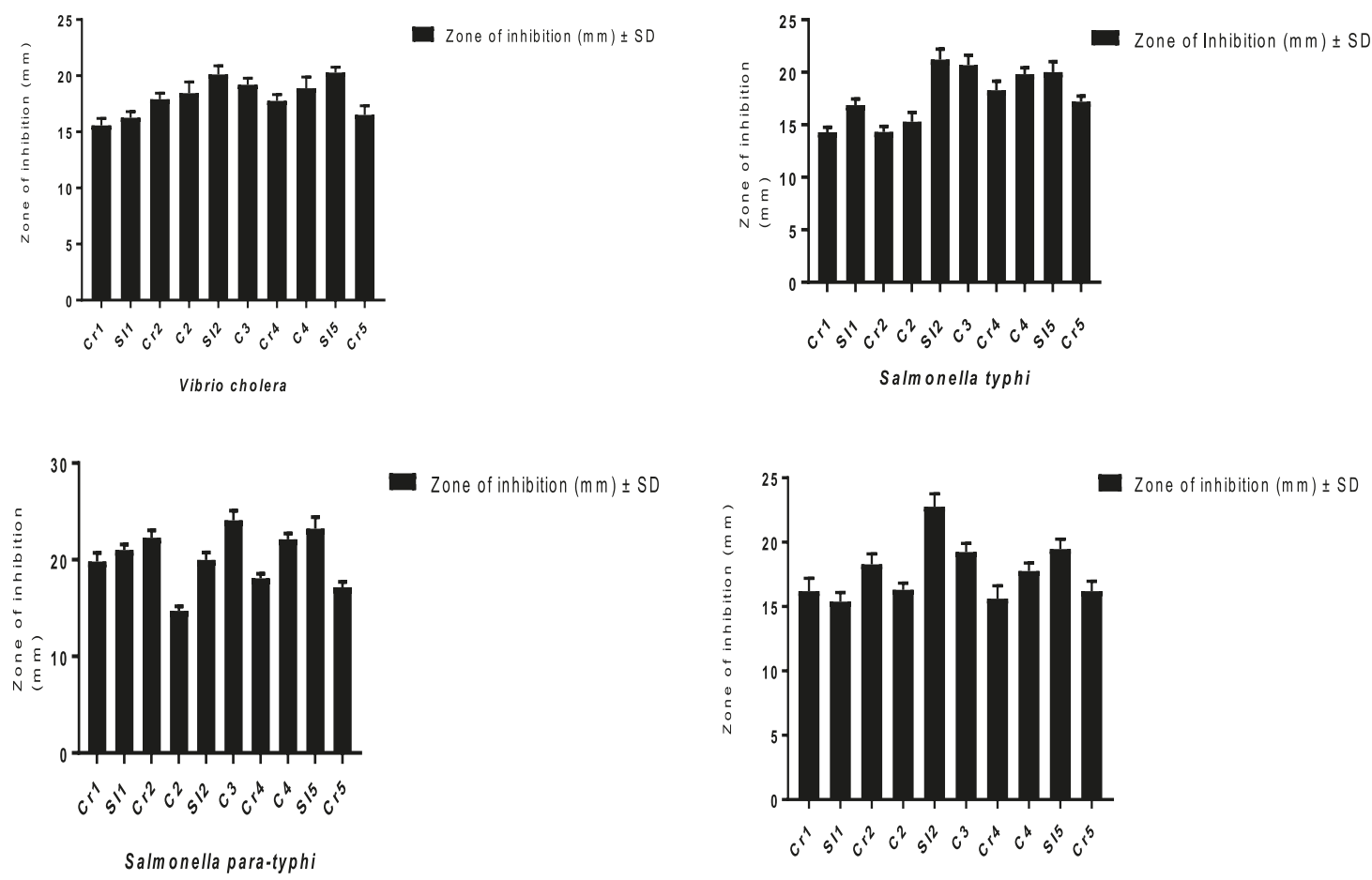

Streptococcus aureus

Figure 1: Antimicrobial activities of the isolates obtained from poultry samples of Khulna and Barisal Divisions

\section{Discussion}

The aims of the present study were to isolate potential probiotics from the gastrointestinal tract of regional poultry samples and explore their probiotic properties. For this purpose, ten isolates were obtained from the crop, ceca and small intestine of different poultry samples of variable ages from Khulna and Barisal Divisions. The bacterial characterization and biochemical analysis, as well as antimicrobial and antibiotic susceptibility tests, were performed by several in vitro assays. The isolation media used for the isolation and maintenance of potential Lactobacilli was MRS media. Some of the compositions of MRS culture media such as Tween 80, acetate, manganese and magnesium which are known to act as special growth factors for Lactobacilli. MRS culture media provides rich nutrient sources to the isolates (De Man, et al., 1960). In the present study, at first colony morphology of the isolates was observed, and then different in vitro tests were carried out for the potentiality of the isolates as probiotics. Initial isolation and identification were based on the morphological appearance and on the catalase test. After performing some preliminary tests (Gram staining and catalase), a total of 10 isolates were selected for further identification. During the catalase test, no bubbles were observed indicating that the isolated bacteria are catalase negative and could not mediate the decomposition of hydrogen peroxide $\left(\mathrm{H}_{2} \mathrm{O}_{2}\right)$ to produce carbon dioxide $\left(\mathrm{CO}_{2}\right)$. All the isolates were also characterized by biochemical and physiological tests. In the in vitro bacteriological tests, all potential probiotic isolates were endospore negative, 
Table 5: The average diameters of zone of inhibition of isolates obtained from poultry Samples of Khulna and Barisal Divisions

\begin{tabular}{|c|c|c|c|c|c|c|c|c|}
\hline \multirow[b]{2}{*}{$\begin{array}{l}\text { Sources of } \\
\text { isolates }\end{array}$} & \multicolumn{8}{|c|}{$\begin{array}{c}\text { Names of the antibiotics } \\
\text { Mean diameter of zone of inhibition }(\mathrm{mm}) \pm \mathrm{SD}\end{array}$} \\
\hline & 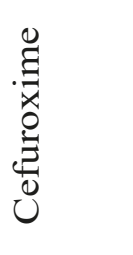 & 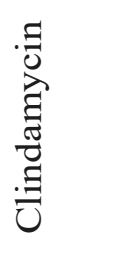 & 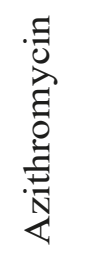 & 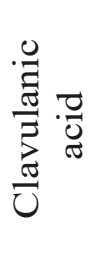 & 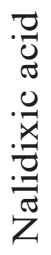 & 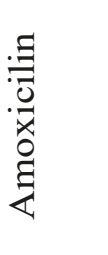 & 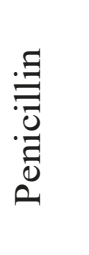 & 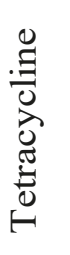 \\
\hline $\mathrm{Cr} 1$ & $\begin{array}{l}21.18 \\
\pm 0.61\end{array}$ & $\begin{array}{l}6.98 \\
\pm 0.54\end{array}$ & $\begin{array}{c}6.78 \\
\pm 0.48\end{array}$ & $\begin{array}{l}20.03 \\
\pm 0.58\end{array}$ & 0 & $\begin{array}{l}34.09 \\
\pm 1.00\end{array}$ & $\begin{array}{l}29.83 \\
\pm 0.76\end{array}$ & 0 \\
\hline SI1 & $\begin{array}{l}23.33 \\
\pm 0.56\end{array}$ & $\begin{array}{l}7.11 \\
\pm 0.5\end{array}$ & $\begin{array}{c}6.7 \\
\pm 0.46 \\
\end{array}$ & $\begin{array}{l}18.89 \\
\pm 0.67\end{array}$ & 0 & $\begin{array}{l}32 \\
\pm 0\end{array}$ & $\begin{array}{c}33.34 \\
\pm 0\end{array}$ & 0 \\
\hline $\mathrm{Cr} 2$ & $\begin{array}{l}23.28 \\
\pm 0.56 \\
\end{array}$ & $\begin{array}{c}7.23 \\
\pm 0.56 \\
\end{array}$ & $\begin{array}{r}8.08 \\
\pm 0.47 \\
\end{array}$ & $\begin{array}{l}20.12 \\
\pm 0.87 \\
\end{array}$ & 0 & $\begin{array}{l}37.56 \\
\pm 1.00 \\
\end{array}$ & $\begin{array}{r}35.11 \\
\pm 1.00 \\
\end{array}$ & 0 \\
\hline $\mathrm{C} 2$ & $\begin{array}{c}24 \\
\pm 0.5\end{array}$ & $\begin{array}{c}8.21 \\
\pm 0.71\end{array}$ & $\begin{array}{l}25.00 \\
\pm 1.00\end{array}$ & $\begin{array}{l}7.11 \\
\pm 0.46\end{array}$ & 0 & $\begin{array}{l}7.00 \\
\pm 0.56\end{array}$ & $\begin{array}{l}18.14 \\
\pm 0.29\end{array}$ & 0 \\
\hline SI2 & $\begin{array}{c}6.02 \\
\pm 0.24\end{array}$ & $\begin{array}{l}26.77 \\
\pm 0.71\end{array}$ & $\begin{array}{l}22.21 \\
\pm 0.49 \\
\end{array}$ & $\begin{array}{l}6.5 \\
\pm 0 \\
\end{array}$ & 0 & $\begin{array}{c}6.94 \\
\pm 0.56\end{array}$ & $\begin{array}{c}8.02 \\
\pm 0.24 \\
\end{array}$ & 0 \\
\hline C3 & $\begin{array}{c}6.67 \\
\pm 0.54 \\
\end{array}$ & $\begin{array}{c}23.43 \\
\pm .58 \\
\end{array}$ & $\begin{array}{l}23.87 \\
\pm 0.98 \\
\end{array}$ & $\begin{array}{c}6.78 \\
\pm 0.29 \\
\end{array}$ & 0 & $\begin{array}{c}6.78 \\
\pm 0.59 \\
\end{array}$ & $\begin{array}{l}6.5 \\
\pm 0\end{array}$ & 0 \\
\hline $\mathrm{Cr} 4$ & $\begin{array}{c}7.56 \\
\pm 0.60\end{array}$ & $\begin{array}{c}21.98 \\
\pm .77\end{array}$ & $\begin{array}{l}26.12 \\
\pm 0.76\end{array}$ & $\begin{array}{l}22.00 \\
\pm 1.00\end{array}$ & 0 & $\begin{array}{l}32.18 \\
\pm 1.00\end{array}$ & $\begin{array}{c}35.00 \\
\pm 0\end{array}$ & 0 \\
\hline C4 & $\begin{array}{c}21.0 \\
\pm 0.58\end{array}$ & $\begin{array}{c}20.09 \\
\pm .56 \\
\end{array}$ & $\begin{array}{c}9.00 \\
\pm 0.76 \\
\end{array}$ & $\begin{array}{l}21.19 \\
\pm 0.76 \\
\end{array}$ & 0 & $\begin{array}{l}31.67 \\
\pm 0.76\end{array}$ & $\begin{array}{l}37.71 \\
\pm 1.00 \\
\end{array}$ & 0 \\
\hline SI5 & $\begin{array}{c}19.87 \\
\pm .60 \\
\end{array}$ & $\begin{array}{c}7.87 \\
\pm 0.76 \\
\end{array}$ & $\begin{array}{r}14.23 \\
\pm 1.00 \\
\end{array}$ & $\begin{array}{l}18.56 \\
\pm 1.00 \\
\end{array}$ & 0 & $\begin{array}{l}31.00 \\
\pm 0.76 \\
\end{array}$ & $\begin{array}{l}29.93 \\
\pm 0.76 \\
\end{array}$ & 0 \\
\hline $\mathrm{Cr} 5$ & $\begin{array}{c}6.67 \\
\pm 0.56\end{array}$ & $\begin{array}{l}10.07 \\
\pm 0.98\end{array}$ & $\begin{array}{l}19.97 \\
\pm 1.50\end{array}$ & $\begin{array}{c}7.17 \\
\pm 0.58\end{array}$ & 0 & $\begin{array}{l}36.78 \\
\pm 1.02\end{array}$ & $\begin{array}{l}36.99 \\
\pm 1.00\end{array}$ & 0 \\
\hline
\end{tabular}

non-motile, catalase negative, gram positive and rod or coccoid shaped. These findings were similar to that of the findings of the research done by (Noohi et al., 2014). The ability of LAB isolates to ferment oligosaccharides is one of the desirable probiotic characteristics because the mono-saccharin that exists in the gastrointestinal tract influences the life of microorganisms in the intestine (Kaplan and Hutkins, 2000). The ability of the isolates to ferment carbohydrates has been demonstrated by the discoloration of 
the red basal medium in yellow color. It was discovered that not all carbohydrates could be fermented from selected isolates. These fermentation patterns of the potential probiotic isolates were similar to the findings of the study of Karna et al. (2007) and Belkacem et al. (2009). The incompatibility in two sugars may be due to the involvement of some factors such as the availability of sufficient D-xylose and D-sorbitol as well as may be due to the lack of ability of the enzyme produced by the isolates to decompose the sugars in the basal medium. In the digestive tract of poultry, the temperature is $42^{\circ} \mathrm{C}$ (Dawson \& Whittow, 2000). Therefore, the isolates that will be able to grow at that temperature should be selected for poultry feed development. The tests were performed to examine the influence of temperature regarding understanding the type of bacteria, belonging to mesophilic or thermophilic groups. The results indicated that only one isolate was not able to grow at $45^{\circ} \mathrm{C}$. The findings of the temperature survivability test were in accordance with a study that concluded from the results of $24 \mathrm{~h}$ observation, all 17 isolates from poultry GIT can grow at $25^{\circ}, 37^{\circ}$ and $45^{\circ} \mathrm{C}$ (Powthong $\&$ Suntornthiticharoen, 2013). In the present study, most of the isolates had high viability at high- temperature conditions.

Probiotic bacteria do show resistance to different acidic conditions (Fontana et al., 2013). In the present study, $\mathrm{pH} 3.5,4.0,5.0$, 8.0 and 9.0 were maintained in the culture media to obtain the growth of the isolates at different $\mathrm{pH}$. They were not able to multiply at $\mathrm{pH} 4.0$ and below. $\mathrm{NaCl}$ is an inhibitory substancethat may inhibit the growth of certain types of bacteria. In the present study, all of the isolates showed tolerance against $1 \%, 2 \%$ and $4 \% \mathrm{NaCl}$ concentrations after 24hours of time. The results observed in a study by Pancheniak and Soccol (2005) summarized that all the isolated strains were able to tolerate 1-6\% $\mathrm{NaCl}$ which correlates with the findings of the present study. In assessing the potential use of lactic bacteria as an effective probiotic, it is generally considered necessary to evaluate their ability to resist the effects of bile salts and acid.

In the present study, isolated bacteria were able to survive in $0.05 \%, 0.15 \%$, and $0.3 \%$ inhibitory substance; bile acids as well as they were also able to multiply in above mentioned concentrations of bile acid. After 24 hours of incubation, all ten isolates showed better results and less inhibition at $0.05 \%$ and $0.15 \%$ concentrations of bile salt than $0.3 \%$, which was similar to the findings of Walker (2000). In the present study, the diameter of inhibition zones showed that, most of the isolates have antimicrobial activity. In vitro antibacterial activity of selected strains belonging to probiotic genera, Lactobacillus, was investigated. In a study, agar spot test showed all the selected strains were antagonistic against Salmonella Typhimurium, Escherichia coli, Enterococcus faecalis, Staphylococcus aureus and Clostridium difficile (Tejero-Sariñena et al., 2012) which indicates the similarity of the findings of the present study.

Another study summarized that most isolated LABs showed a large zone of inhibition for Salmonella para-typhi, Escherichia coli, and Shigella flexneri, respectively (Powthong and Suntornthiticharoen, 2013) which is also similar to the findings of the present study. 
In the present study, variation in antibiotic sensitivity pattern is similar to the findings of a study by Toomey et al. (2009) who reported that resistance among Lactobacilli isolates appeared to vary between species. In the present study, all the isolates were resistant to tetracycline which correlates with the findings of Roberts (2005) and Korhonen et al., (2008) who showed that resistance to tetracycline has been observed more often among Lactobacilli. The susceptibility patterns of the isolates in this study to azithromycin and clindamycin have similarities with the findings of Powthong and Suntornthiticharoen (2013). Almost all the isolates of the present study were susceptible to penicillin and amoxicillin which have similarities with the findings of Danielsen and Wind (2003) and Bakari et al. (2011) who reported that generally Lactobacilli seem to be sensitive to these two types of antibiotics. In the present study, isolate no 1, 2, 3, 7, 8 and 9 were susceptible to clavulanic acid and cefuroxime which were similar to the findings of Bakari et al. (2011). Resistance to clavulanic acid, cefuroxime, penicillin and amoxicillin of some isolates is not intrinsic to Lactobacilli; therefore, it might be important to study for the presence of known genes providing such resistance in these strains.

\section{Conclusion}

A total of ten potential native probiotic isolates were obtained from the selective gastrointestinal tract region of poultry from Khulna and Barisal Divisions. They were identified on the basis of in vitro tests for bacterial characterization as well as their probiotic potentialities. They did show good probiotic characteristics like growth at different temperatures, $\mathrm{pH}$, bile tolerance,
$\mathrm{NaCl}$ tolerance, gastrointestinal juice tolerance. They were also assayed for their antimicrobial activity and antibiotic sensitivity patterns.

\section{Acknowledgement}

The authors are grateful to the authority of Project Implementation Unit, National Agricultural Technology Program, Phase-II (NATP-2), Bangladesh Agricultural Research Council (BARC) for providing fund under Competitive Research Grant (CRG) sub-project by the World Bank.

\section{References}

Adlerberth, M.C., Marina Cerquetti,Isabelle Poilane, Agnes Wold and Anne Collignon. 2000. Mechanisms of colonisation and colonisation resistance of the digestive tract part 1: bacteria/host interactions. Microbial Ecology in Health and Disease, 12(2): 223-239.

Aliakbarpour, H., Chamani, M., Rahimi, G., Sadeghi, A. and Qujeq, D. J. A.-A. j. o. a. s. 2012. The Bacillus subtilis and lactic acid bacteria probiotics influences intestinal mucin gene expression, histomorphology and growth performance in broilers. Asian-Australas J Anim Sci.,25(9): 1285-1293.

Ali, M.Z., Islam, M.M. and Zaman, S., 2020. Effects of Turmeric Powder on Clostridium Perfringens Load in Broiler Chickens. SAARC Journal of griculture, 18(1): pp.209-218.

Bakari, D., Tatsadjieu, N.L., Mbawala, A. and Mbofung, C.M. 2011. Assessment of physiological properties of some 
lactic acid bacteria isolated from the intestine of chickens use as probiotics and antimicrobial agents against enteropathogenic bacteria. Innovative Romanian Food Biotechnology, 8:33-40.

Belkacem, B., Meriem, M. and Mebrouk, K. 2009. Probiotic potential of thermotolerants lactobacilli isolated from chicken gastrointestinal digestive and their use as poultry feed. World Appl Sci J, 7: 951-957.

Coeuret, V., Dubernet, S., Bernardeau, M., Gueguen, M., and Vernoux, J. P. J. L. L. 2003. Isolation, characterisation and identification of lactobacilli focusing mainly on cheeses and other dairy products. Dairy Science \& Technology,83(4): 269-306.

Coico, R., 2006. Gram staining. Current Protocols in Microbiology, (1): pp.A-3C.

Corcionivoschi, N., Drinceanu, D., Stef, L., Luca, I. and Julean, C. J. I. R. F. B. 2010. Probiotics-identification and ways of action. Innovative Romanian Food Biotechnology,6: 1-11.

Cotter, P.D., Ross, R.P. \& Hill, C.J. N. R. M. 2013. Bacteriocins-a viable alternative to antibiotics? Nat Rev Microbiol,11(2): 95-105.

Danielsen, M. and Wind, A. 2003. Susceptibility of Lactobacillus spp. to antimicrobial agents. International Journal of Food Microbiology, 82(1): 1-11.

Dawson, W. and Whittow, G. 2000. Regulation of body temperature. In: Sturkie's Avian Physiology, Fifth Edition, Elsevier: 343-390.
De Man, J., Rogosa, d. \& Sharpe, M.E. 1960. A medium for the cultivation of lactobacilli. Journal of Applied Bacteriology, 23(1): 130-135.

Fontana, L., Bermudez-Brito, M., Plaza-Diaz, J., Munoz-Quezada, S. and Gil, A. 2013. Sources, isolation, characterisation and evaluation of probiotics. British Journal of Nutrition, 109(S2): S35-S50.

Gismondo, M., Drago, L. and Lombardi, A. 1999. Review of probiotics available to modify gastrointestinal flora. International Journal of Antimicrobial Agents, 12(4): 287-292.

Hedberg, M., Hasslöf, P., Sjöström, I., Twetman, S. and Stecksén-Blicks, C., 2008. Sugar fermentation in probiotic bacteria-an in vitro study. Oral Microbiology and Immunology, 23(6): pp.482-485.

Holzapfel, W.H., Haberer, P., Geisen, R., Björkroth, J. and U. Schillinger 2001. Taxonomy and important features of probiotic microorganisms in food and nutrition. Am J Clin Nut,73(2): 365S-373S.

Ibrahim, F., Ruvio, S., Granlund, L., Salminen, S., Viitanen, M. and A.C. Ouwehand 2010.

Probiotics and immunosenescence: cheese as a carrier. Immunol. Med. Microbiol., 59(1): 53-59.

Ishibashi, N. and Yamazaki, S. 2001. Probiotics and safety. The American Journal of Clinical Nutrition,73(2: 465s-470s. 
Jorgensen, J.H., Hindler, J.F., Reller, L.B. and Weinstein, M.P., 2007. New consensus guidelines from the Clinical and Laboratory Standards Institute for antimicrobial susceptibility testing of infrequently isolated or fastidious bacteria. Clinical Infectious Diseases, 44(2): pp.280-286.

Kaplan, H. and Hutkins, R.W. 2000. Fermentation of fructooligosaccharides by lactic acid bacteria and bifidobacteria. Applied and Environmental Microbiology, 66(6): 2682-2684.

Karna, B., Barraquio, V.L. and Emata, O. 2007. Lactic acid and probiotic bacteria from fermented and probiotic dairy products. Science Diliman, 19(2): 23-34.

Korhonen, J., Danielsen, M., Mayo, B., Egervärn, M., Axelsson, L., Huys, G. and Von Wright, A. 2008. Antimicrobial susceptibility and proposed microbiological cut-off values of lactobacilli by phenotypic determination. International Journal of Probiotics and Prebiotics, 3: 257-268.

Lilly, D.M. and Stillwell, R.H.J.S. 1965. Probiotics: growth-promoting factors produced by microorganisms. Science 147(3659): 747-748.

Mohan, V.J.E.J.O.C.M. and Diseases, I. 2015. The role of probiotics in the inhibition of Campylobacter jejuni colonization and virulence attenuation. Eur. J. Clin. Microbiol. Infect. Dis., 34(8):1503-1513.

Noohi, N., Ebrahimipour, G., Rohani, M.,
Talebi, M., and Pourshafie, M.R. 2014. Phenotypic characteristics and probiotic potentials of Lactobacillus spp. isolated from poultry. Jundishapur Journal of Microbiology, 7(9):e17824.

Ouwehand, A.C., Salminen, S. and Isolauri, E. 2002. Probiotics: an overview of beneficial effects. In: Lactic Acid Bacteria: Genetics, Metabolism and Applications. Springer: 279-289.

Pancheniak, E.D.F.R. and Soccol, C.R. 2005. Biochemical characterization and identification of probiotic Lactobacillus for swine. Boletim do Centro de Pesquisa de Processamento de Alimentos, 23(2): 299-310.

Powthong, P. and Suntornthiticharoen, P. 2013. Antibacterial and probiotic properties of lactic acid bacteria isolated from chicken intestine, entrails of swine, and soil against gastrointestinal and urogenital pathogens. World Journal of Pharmacy and Pharmaceutical Science, 4: 1-18.

Roberts, M. C. 2005. Update on acquired tetracycline resistance genes. FEMS Microbiology Letters, 245(2): 195-203.

Soccol, C.R., de Souza Vandenberghe, L. P., Spier, M.R., Medeiros, A.P., Yamaguishi, C.T., J De

Dea Lindner, Pandey A and Thomaz-Soccol V 2010. The potential of probiotics: a review.

Food Technology and Biotechnology, 48(4): 413-434. Tejero-Sariñena, S., Barlow, J., Costabile, A., Gibson, G.R., and Rowland, I. 2012. In vitro evaluation of the antimicrobial activity of a range of 
probiotics against pathogens: evidence for the effects of organic acids. Anaerobe,18(5): 530-538.

Toomey, N., Monaghan, Á., Fanning, S. and Bolton, D. 2009. Transfer of antibiotic resistance marker genes between lactic acid bacteria in model rumen and plant environments. Applied and Environmental Microbiology, 75(10): 3146-3152.
Walker, W.A. 2000. Role of nutrients and bacterial colonization in the development of intestinal host defense. Journal of Pediatric Gastroenterology and Nutrition, 30: S2-S7. 